Article

\title{
The Hydrophobin HYTLO1 Secreted by the Biocontrol Fungus Trichoderma longibrachiatum Triggers a NAADP-Mediated Calcium Signalling Pathway in Lotus japonicus
}

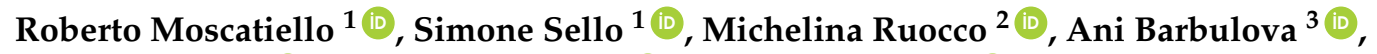 \\ Enrico Cortese ${ }^{1}$ (i), Sebastiano Nigris ${ }^{4}$ (i), Barbara Baldan ${ }^{1,4}$ (1), Maurizio Chiurazzi ${ }^{3}$ (i), \\ Paola Mariani ${ }^{1}$, Matteo Lorito ${ }^{5}$ and Lorella Navazio ${ }^{1,4, * \text { (iD }}$ \\ 1 Department of Biology, University of Padova, Via U. Bassi 58/B, 35131 Padova, Italy; \\ roberto.moscatiello@unipd.it (R.M); sello.simone@gmail.com (S.S.); enrico.cortese.1@phd.unipd.it (E.C.); \\ barbara.baldan@unipd.it (B.B.); mariani@bio.unipd.it (P.M.) \\ 2 Institute for Sustainable Plant Protection, CNR, Via Università 133, 80055 Portici (NA), Italy; \\ michelina.ruocco@ipsp.cnr.it \\ 3 Institute of BioSciences and BioResourses, CNR, Via P. Castellino 111, 80131 Napoli, Italy; \\ ani@arterrabio.it (A.B.); maurizio.chiurazzi@ibbr.cnr.it (M.C.) \\ 4 Botanical Garden, University of Padova, Via Orto Botanico 15, 35123 Padova, Italy; \\ sebastiano.nigris@unipd.it \\ 5 Department of Agricultural Sciences, University of Napoli "Federico II", Via Università 100, \\ 80055 Portici (NA), Italy; lorito@unina.it \\ * Correspondence: lorella.navazio@unipd.it; Tel.: +39-049-827-6295
}

Received: 30 July 2018; Accepted: 29 August 2018; Published: 1 September 2018 updates

\begin{abstract}
Trichoderma filamentous fungi are increasingly used as biocontrol agents and plant biostimulants. Growing evidence indicates that part of the beneficial effects is mediated by the activity of fungal metabolites on the plant host. We have investigated the mechanism of plant perception of HYTLO1, a hydrophobin abundantly secreted by Trichoderma longibrachiatum, which may play an important role in the early stages of the plant-fungus interaction. Aequorin-expressing Lotus japonicus suspension cell cultures responded to HYTLO1 with a rapid cytosolic $\mathrm{Ca}^{2+}$ increase that dissipated within $30 \mathrm{~min}$, followed by the activation of the defence-related genes MPK3, WRK33, and CP450. The $\mathrm{Ca}^{2+}$-dependence of these gene expression was demonstrated by using the extracellular $\mathrm{Ca}^{2+}$ chelator EGTA and Ned-19, a potent inhibitor of the nicotinic acid adenine dinucleotide phosphate (NAADP) receptor in animal cells, which effectively blocked the HYTLO1-induced $\mathrm{Ca}^{2+}$ elevation. Immunocytochemical analyses showed the localization of the fungal hydrophobin at the plant cell surface, where it forms a protein film covering the plant cell wall. Our data demonstrate the $\mathrm{Ca}^{2+}$-mediated perception by plant cells of a key metabolite secreted by a biocontrol fungus, and provide the first evidence of the involvement of NAADP-gated $\mathrm{Ca}^{2+}$ release in a signalling pathway triggered by a biotic stimulus.
\end{abstract}

Keywords: aequorin; biocontrol fungi; calcium signalling; Lotus japonicus; hydrophobins; HYTLO1; NAADP; Trichoderma

\section{Introduction}

Trichoderma is a widely spread genus of free-living filamentous fungi belonging to Ascomycota, increasingly used in agricultural applications as biocontrol agents and biofertilizers [1-5]. The effects exerted by Trichoderma at the plant level are both indirect, due to the mycoparasitic activity on 
a plethora of phytopathogens, and direct, due to the induction of plant defence responses and promotion of growth and development [6]. For its peculiar lifestyle traits, plant root colonization and favourable impact on plant physiology, Trichoderma has been defined as an opportunistic, avirulent plant symbiont [7]. Although the beneficial effects produced by Trichoderma on the plant have been extensively demonstrated, little is known about the molecular mechanisms underlying signal transduction during the early stages of the interactions of plants with these biocontrol fungi. The induction of pathogen resistance is accomplished through the secretion of a complex arsenal of fungal molecules encompassing cell wall-degrading enzymes, secondary metabolites with antibiotic activity, and other substances [8]. Culture filtrates of Trichoderma atroviride, grown alone or in co-culture with the phytopathogen Botrytis cinerea, have been shown to induce in soybean cell cultures transient elevation in cytosolic free $\mathrm{Ca}^{2+}$ concentrations and defence responses, such as reactive oxygen accumulation and programmed cell death [9]. Nevertheless, the molecular mechanisms causing the observed effects on the plant host has been determined only for a few of the many secreted metabolites found in Trichoderma [10].

Calcium is a universal signalling element involved in a plethora of transduction pathways in all eukaryotes [11-13], as well as in prokaryotes [14]. In plants, $\mathrm{Ca}^{2+}$ has been demonstrated to mediate a wide array of signalling cascades in response to both abiotic and biotic stimuli [15-17]. Changes in intracellular free $\mathrm{Ca}^{2+}$ levels are a common early event during many plant-microbe interactions, of both symbiotic and pathogenic nature [18]. In particular, the role of $\mathrm{Ca}^{2+}$ signalling in the establishment of plant defence responses has been known for many years [19].

In this work we have investigated the mechanism of plant perception and transduction of HYTLO1, a hydrophobin abundantly secreted in the culture medium by Trichoderma longibrachiatum strain MK1 [20]. Hydrophobins are a family of small amphypathic proteins found exclusively in filamentous fungi, which are known to mediate the interactions between the fungus and its environment. In addition to having a general role during formation of aereal hyphae, sporulation, and production of fruit bodies, hydrophobins are thought to be involved in plant-fungus interactions, both pathogenic and symbiotic, by mediating the adhesion of fungal hyphae to the root surface [21]. Information about the role of hydrophobins in biocontrol fungi in plant root colonization, induction of plant defences, antifungal activity against phytopathogens, as well as responses to abiotic stresses is rapidly emerging [20,22,23]. A Trichoderma mutant, defective for the TasHyd1 gene encoding a hydrophobin, although unaffected in its mycoparasitic activity, was found to be unable to colonize the plant root apparatus [24].

By using the model legume Lotus japonicus $[25,26]$ stably expressing the genetically encoded $\mathrm{Ca}^{2+}$ indicator aequorin, we demonstrated that HYTLO1 triggers in plant cells a signal transduction pathway leading to the activation of defence genes in a $\mathrm{Ca}^{2+}$-dependent manner. Experiments performed by using the chemical probe Ned-19 [27] showed that the $\mathrm{Ca}^{2+}$ signalling pathway activated by HYTLO1 is mediated by nicotinic acid adenine dinucleotide phosphate (NAADP), a metabolite of nicotinamide adenine dinucleotide phosphate (NADP) which has been demonstrated to act as a potent $\mathrm{Ca}^{2+}$ mobilizing messenger in a wide variety of eukaryotes (see [28] for a review), including plants [29], as well as green and brown macroalgae [30,31]. The obtained data provide the first evidence for the involvement of this pyridine nucleotide-based $\mathrm{Ca}^{2+}$ agonist in a physiological event in higher plants and offer new insights into the mechanism of action of fungal hydrophobins.

\section{Results}

\subsection{Generation of Transgenic L. japonicus Plants Stably Expressing the Bioluminescent $\mathrm{Ca}^{2+}$ Reporter Aequorin}

To investigate the potential participation of calcium in the plant perception of HYTLO1, we transformed Lotus japonicus with a cDNA construct encoding the bioluminescent $\mathrm{Ca}^{2+}$ reporter aequorin. L. japonicus is a well-characterized model legume, widely used as an experimental system to 
analyse different types of plant-microbe interactions along the symbiosis-pathogenesis spectrum [32]. The aequorin coding sequence was cloned between the Cauliflower Mosaic Virus 35S promoter (CaMV $35 \mathrm{~S}$ ) and the Agrobacterium tumefaciens nopaline synthase terminator (tNOS) sequences in the pCAMBIA vector [33] to obtain the T-DNA construct pAB1 (Figure S1A). PAB1 was then used for Agrobacterium tumefaciens-mediated transformation-regeneration procedure of L. japonicus $[34,35]$ wild-type and Ljsym4-2 mutant, where the latter is impaired in the symbioses with both arbuscular mycorrhizal (AM) fungi and rhizobia [36]. Transgenic plants were selected on hygromycin-containing medium and allowed to self-pollinate. Several independent lines of the first generation of transformants (T1), showing a hygromycin resistance segregation of 3:1 were tested by semi-quantitative RT-PCR to confirm aequorin expression and analyse the amount of transcript in the different transgenic lines. Homozygous plants of the second generation (T2), exhibiting the highest aequorin expression (Figure S1B), were selected to set up in vitro cell cultures. Suspension-cultured cells are particularly useful to understand some complex plant physiological processes, such as $\mathrm{Ca}^{2+}$-mediated signal transduction events $[37,38]$.

\subsection{The Hydrophobin HYTLO1 Triggers a Transient Cytosolic $\mathrm{Ca}^{2+}$ Elevation in Aequorin-Expressing Lotus} japonicus Cells

HYTLO1, the major hydrophobin secreted by the strain MK1 of Trichoderma longibrachiatum, has been previously isolated from the culture medium of the biocontrol fungus, purified to homogeneity, and cloned [20]. To check if the perception and signal transduction of this protein involves calcium as intracellular messenger, aequorin-expressing L. japonicus cell suspension cultures derived from the transgenic plants were challenged with HYTLO1. The hydrophobin $(0.6 \mu \mathrm{M})$ was found to trigger a transient cytosolic $\mathrm{Ca}^{2+}$ increase that peaked $(0.48 \pm 0.09 \mu \mathrm{M} ; \mathrm{n}=10)$ about 6 min after the injection and slowly dissipated within $30 \mathrm{~min}$. The kinetics of the cytosolic $\mathrm{Ca}^{2+}$ change $\left(\left[\mathrm{Ca}^{2+}\right]_{\text {cyt }}\right)$ was very similar in L. japonicus wild-type cells and Ljsym4-2 mutant cells, stably expressing cytosolic aequorin (Figure 1A). The Ljsym4-2 mutant is defective in the CASTOR gene that encodes a cation channel essential for nuclear and perinuclear $\mathrm{Ca}^{2+}$ spiking in legume root endosymbiosis [39-41].

As a comparison, the cytosolic $\mathrm{Ca}^{2+}$ transients evoked by the symbiotic signalling molecules Myc factors and Nod factors, produced by the arbuscular mycorrhizal fungus Gigaspora margarita and the specific rhizobial symbiont Mesorhizobium loti are respectively shown in Figure 1B,C. In these latter two cases the $\mathrm{Ca}^{2+}$ traces exhibited by the Ljsym4-2 mutant differ from the wild-type for the lack of the second, flattened dome-shaped $\left[\mathrm{Ca}^{2+}\right]_{\text {cyt }}$ elevation (after about $15 \mathrm{~min}$ ), which is consistent with the sum of the perinuclear $\mathrm{Ca}^{2+}$ oscillations that were visualized in $\mathrm{Ca}^{2+}$ imaging experiments in L. japonicus wild-type, but not CASTOR mutant [39]. 
A

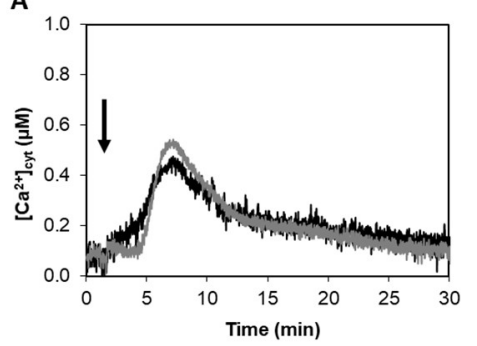

B

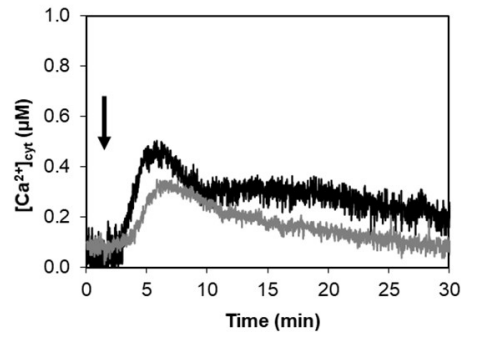

C

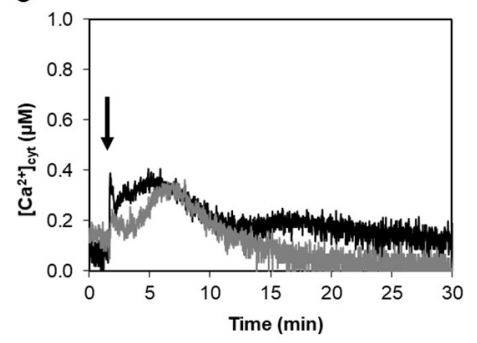

Figure 1. Monitoring of cytosolic $\mathrm{Ca}^{2+}$ concentration $\left(\left[\mathrm{Ca}^{2+}\right]_{\text {cyt }}\right)$ in aequorin-expressing L. japonicus in response to different biotic stimuli. Suspension-cultured cells of L. japonicus wild-type (black trace) and Ljsym4-2 mutant (grey trace), stably transformed with a cDNA construct encoding cytosolic aequorin, were treated with: (A) the hydrophobin HYTLO1 $(0.6 \mu \mathrm{M})$ purified from the biocontrol fungus T. longibrachiatum; (B) Myc factors from the AM fungus G. margarita; (C) Nod factors from the nitrogen-fixing symbiotic bacterium M. loti. Arrows indicate the time (100 s) of stimulation. These and the following traces are representative of at least 6 independent experiments that gave similar results.

\subsection{HYTLO1 Activates the Expression of Defence Genes in L. japonicus Cells, but Does Not Induce Cell Death}

We next evaluated the effect of the treatment of L. japonicus cells with HYTLO1 on the expression of some genes commonly involved in plant defence against phytopathogens, namely MPK3, encoding the mitogen-activated protein kinase 3, WRKY33, encoding the transcription factor WRK33, CP450, encoding the cytochrome P450, and PR1, encoding the pathogenesis-related protein 1. Exponentially growing L. japonicus cells of the wild-type line and Ljsym4-2 mutant line were treated with $0.6 \mu \mathrm{M}$ HYTLO1 for $2 \mathrm{~h}, 6 \mathrm{~h}$, and $24 \mathrm{~h}$. Semi-quantitative RT-PCR analyses conducted with the wild-type cells showed a variable range of responses to the HYTLO1 application. MPK3 and WRKY33 were significantly up-regulated ( $1.88 \pm 0.09$ and $1.61 \pm 0.02$, respectively) after $2 \mathrm{~h}$ of treatment, with a subsequent decay to basal expression levels in the following $24 \mathrm{~h}$ (Figure 2A,B). The CP450 gene, although remaining at constitutive level after $2 \mathrm{~h}$ of treatment with HYTLO1, gradually increased its expression after $6 \mathrm{~h}(1.67 \pm 0.43)$ up to more than a three-fold induction level compared to the control ( $3.61 \pm 0.78$ ) after $24 \mathrm{~h}$ (Figure 2C). On the other hand, the expression of PR1 was not significantly modified by the treatment with $0.6 \mu \mathrm{M}$ HYTLO1 for any of the considered time intervals (Figure 2D). Concerning the Ljsym4-2 mutant line, the gene expression analysis showed a trend similar to that observed in the wild-type line, but with lower values (Figure 2A-D). 
A

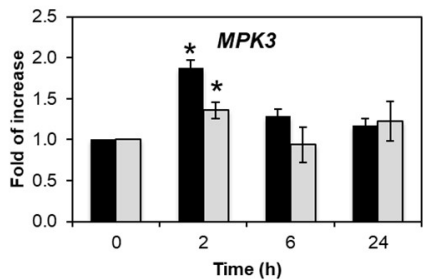

c

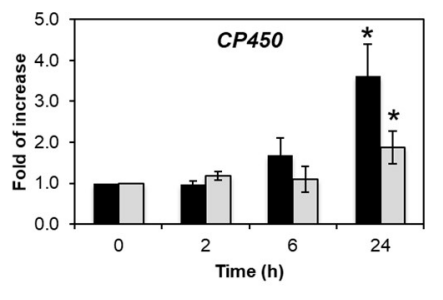

B

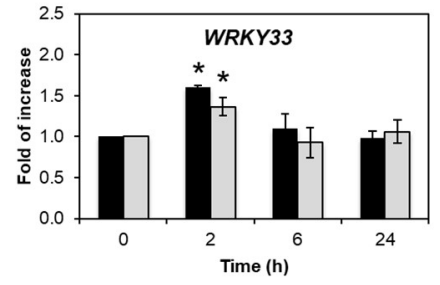

D

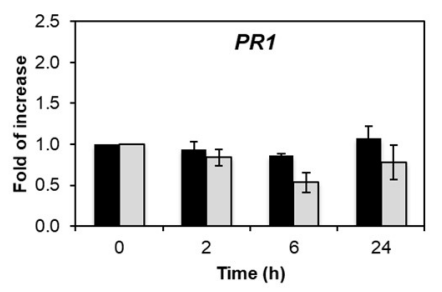

$\square$ Ljsym 4-2

Figure 2. Analysis of HYTLO1-induced gene expression in L. japonicus cells. Semi-quantitative RT-PCR analysis of L. japonicus MPK3 (A), WRK33 (B), CP450 (C), and PR1 (D) in aequorin-expressing L. japonicus cell cultures of the wild-type line (black bars) and Ljsym4-2 mutant line (grey bars) in control conditions and after treatment with HYTLO1 $(0.6 \mu \mathrm{M})$ for different time intervals. Data are the means \pm SE of three independent experiments. ${ }^{*}$ indicates statistically significant difference at $P<0.05$.

The results concerning the statistically significant differences between HYTLO1-treated samples and controls were validated by quantitative RT-PCR (Figure S2). Taken together, these data indicate that HYTLO1 can be considered as a mild elicitor of plant defence responses.

To evaluate the potential cytotoxicity of the fungal hydrophobin, we tested the viability of L. japonicus cells by using the Evans blue method [42]. This colorimetric assay revealed that the percentage of dead cells after treatment with HYTLO1 at $0.6 \mu \mathrm{M}$ for up to $24 \mathrm{~h}$ did not significantly differ from that of control cells (Figure 3).

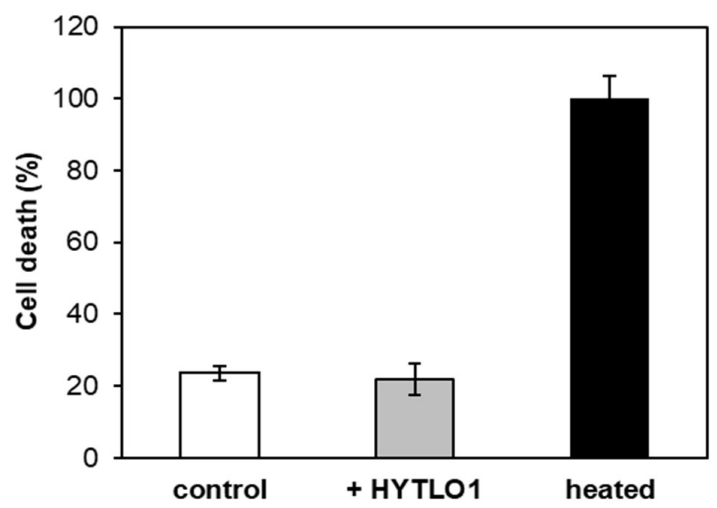

Figure 3. Effect of HYTLO1 on L. japonicus cell viability. Cell suspension cultures were treated with $0.6 \mu \mathrm{M}$ HYTLO1 (grey bar) for $24 \mathrm{~h}$. Cells incubated with the same percentage of ethanol (white bar) were used as control. $100 \%$ cell death corresponds to cells incubated for $20 \mathrm{~min}$ at $100{ }^{\circ} \mathrm{C}$ (black bar). Cell viability was determined by the Evans blue method. Data are the means $\pm \mathrm{SE}$ of three independent experiments.

\subsection{Origin of the HYTLO1-Elicited Cytosolic $\mathrm{Ca}^{2+}$ Fluxes in L. japonicus}

To assess whether the transient elevation in $\left[\mathrm{Ca}^{2+}\right]_{\text {cyt }}$ induced by HYTLO1 in L. japonicus plays a key role in the signalling pathway leading to the activation of defence genes, the effect of the 
abolition of the $\mathrm{Ca}^{2+}$ change on downstream responses was analysed. Experiments based on the use of $\mathrm{Ca}^{2+}$ chelators, inhibitors of $\mathrm{Ca}^{2+}$ channels and of enzymes involved in the generation of $\mathrm{Ca}^{2+}$ mobilizing agents were carried out in the attempt to effectively block the HYTLO1-induced $\left[\mathrm{Ca}^{2+}\right]_{\text {cyt }}$ transient. When cells, 10 minutes before HYTLO1 administration, were transferred to a culture medium depleted of $\mathrm{CaCl}_{2}$ and containing $600 \mu \mathrm{M}$ EGTA, about $56 \%$ reduction of the $\left[\mathrm{Ca}^{2+}\right]_{\text {cyt }}$ peak was observed (Figure 4). Pre-treatment with $100 \mu \mathrm{M}$ Ned-19, a competitive antagonist of the intracellular $\mathrm{Ca}^{2+}$-mobilizing agent NAADP [27], caused inhibition of $\sim 47 \%$ of the $\mathrm{Ca}^{2+}$ transient (Figure 4). These data indicate that in L. japonicus cells HYTLO1 mobilizes $\mathrm{Ca}^{2+}$ from both the extracellular space and from an intracellular compartment sensitive to NAADP. Moreover, the two stores (external and internal) seem to be involved almost at the same extent as sources of the ion for the transduction of this signal. As expected, the $\left[\mathrm{Ca}^{2+}\right]_{\text {cyt }}$ elevation evoked by HYTLO1 was very efficiently blocked $(83.2 \pm 3.5 \%)$ by pre-treating L. japonicus cells with EGTA $(600 \mu \mathrm{M})$ in combination with Ned-19 $(100 \mu \mathrm{M})$ in $\mathrm{Ca}^{2+}$-free medium (Figure 4). $\mathrm{LaCl}_{3}(3 \mathrm{mM})$, a widely used inhibitor of $\mathrm{Ca}^{2+}$-permeable channels located at the plasma membrane [43], caused a reduction of only $~ 33 \%$ of the HYTLO1-Ca ${ }^{2+}$ transient (Figure 4), suggesting that additional $\mathrm{Ca}^{2+}$ channels are involved in the $\mathrm{Ca}^{2+}$ influx activated by HYTLO1 from the extracellular medium. Nicotinamide $(100 \mu \mathrm{M})$, an inhibitor of ADP-ribosyl cyclase, involved in the production of both cyclic ADP-ribose (cADPR) and NAADP [44,45], reduced by $\sim 40 \%$ the $\left[\mathrm{Ca}^{2+}\right]_{\text {cyt }}$ in response to HYTLO1 (Figure 4), confirming the participation of NAADP-gated $\mathrm{Ca}^{2+}$ channels in the generation of HYTLO1-induced $\mathrm{Ca}^{2+}$ fluxes.

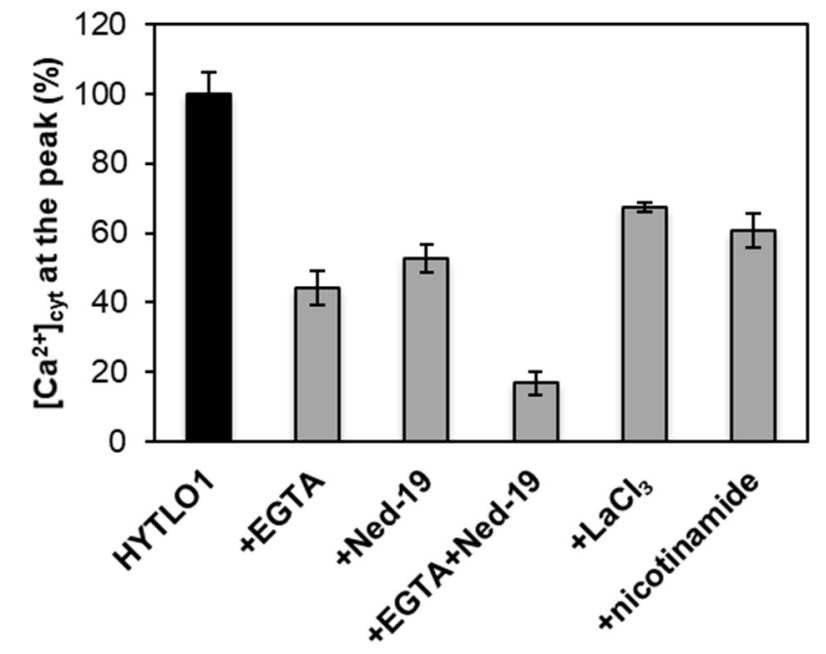

Figure 4. Pharmacological approach for the analysis of cytosolic $\mathrm{Ca}^{2+}$ fluxes induced by HYTLO1 in L. japonicus cells. Cell samples were incubated with: EGTA $(600 \mu \mathrm{M})$, Ned-19 $(100 \mu \mathrm{M})($ singly or in combination with EGTA), $\mathrm{LaCl}_{3}(3 \mathrm{mM})$, nicotinamide $(100 \mu \mathrm{M})$. After $10 \mathrm{~min}$ (EGTA, $\mathrm{LaCl}_{3}$, nicotinamide) or $30 \mathrm{~min}$ (Ned-19), cells were challenged with HYTLO1 $(0.6 \mu \mathrm{M})$. For assays performed with EGTA, cells were previously washed extensively and resuspended in $\mathrm{Ca}^{2+}$-free medium. Data are the means \pm SE of five independent experiments.

\subsection{HYTLO1-Induced Activation of Defence Gene Expression is $\mathrm{Ca}^{2+}$-Dependent}

In view of the efficient inhibition of the HYTLO1-induced $\mathrm{Ca}^{2+}$ transient obtained by the pre-treatment of L. japonicus cells with $600 \mu \mathrm{M}$ EGTA and $100 \mu \mathrm{M}$ Ned-19 in $\mathrm{Ca}^{2+}$-free medium (Figure 5A), the same experimental condition was used to examine the effect of the abolition of the HYTLO1-induced $\mathrm{Ca}^{2+}$ signalling pathway at the level of gene expression. The change of expression of the defence genes MPK3 and WRKY33, observed after $2 \mathrm{~h}$ treatment of wild-type cells with $0.6 \mu \mathrm{M}$ HYTLO1 (Figure 2A,B), was reduced by more than $85 \%$ in the presence of EGTA + Ned-19 (Figure 5B). This result demonstrates that the activation of MPK3 and WRKY33 gene expression in response to HYTLO1 is $\mathrm{Ca}^{2+}$-dependent. 
A

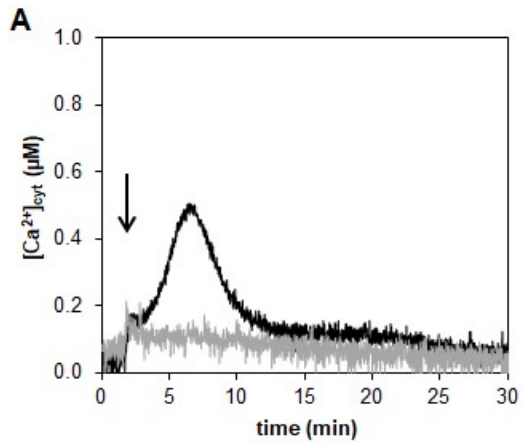

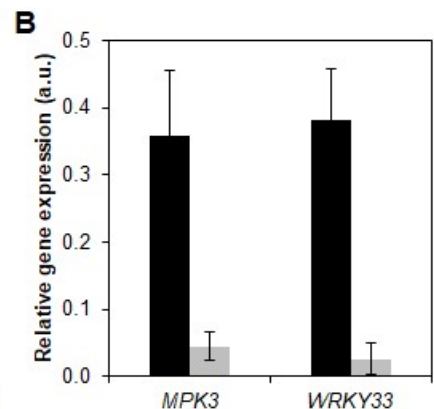

Figure 5. Effect of pretreatment with EGTA and Ned-19 on HYTLO1-induced $\left[\mathrm{Ca}^{2+}\right]_{\text {cyt }}$ transient and gene expression in L. japonicus cells. (A) Monitoring of $\left[\mathrm{Ca}^{2+}\right]_{\mathrm{cyt}}$ in L. japonicus after treatment (arrow) with $0.6 \mu \mathrm{M}$ HYTLO1 in regular cell culture medium (black trace) or after pretreatment with $600 \mu \mathrm{M}$ EGTA and $100 \mu \mathrm{M}$ Ned-19 in $\mathrm{Ca}^{2+}$-free medium (grey trace). (B) RT-PCR analysis of the expression of MPK3 and WRKY33 after treatment with HYTLO1 $(0.6 \mu \mathrm{M})$ for $2 \mathrm{~h}$ in regular medium (black bar) or in $\mathrm{Ca}^{2+}$ free medium supplemented with $600 \mu \mathrm{M}$ EGTA and $100 \mu \mathrm{M}$ Ned-19 (grey bar).

Even the expression of the CP450 gene after $24 \mathrm{~h}$ HYTLO1 treatment was found to be significantly inhibited ( $95 \%$ ) by pre-treatment with EGTA + Ned-19 (Figure S3A). However, this result must be interpreted with caution; in fact, despite treatment with HYTLO1 not causing, by itself, any significant change in cell viability compared with the control (Figure 3), the pre-treatment with EGTA + Ned-19 caused, after $24 \mathrm{~h}$, a significant rise of the cell death (Figure S3B). These data indicate the uselessness of a gene expression analysis after such a prolonged incubation time of the suspension-cultured cells with the above $\mathrm{Ca}^{2+}$ chelator and $\mathrm{Ca}^{2+}$ channel inhibitor.

\subsection{HYTLO1 Perception Occurs at the Plant Cell Surface}

Negative staining with $1 \%$ uranile acetate of a preparation of HYTLO1, dissolved in $50 \%$ ethanol, showed that this protein, similarly to other type II hydrophobins [20], forms in aqueous solution spherical air mycelles by autoassembling in amphypatic monolayer (Figure S4). Immunofluorescence analysis of HYTLO1-treated L. japonicus cells carried out with affinity-purified polyclonal antibodies raised against the purified protein indicated that HYTLO1 interacts with the plant cell surface, with no evidence for protein internalization inside the cell within $24 \mathrm{~h}$ (Figure S5).

Immunogold labelling observations showed that HYTLO1 covers the plant cell wall external surface by forming a protein film (Figure 6), with some evidence for the permeation of the fungal hydrophobin across the plant cell wall (Figure 6 and Figure S6).

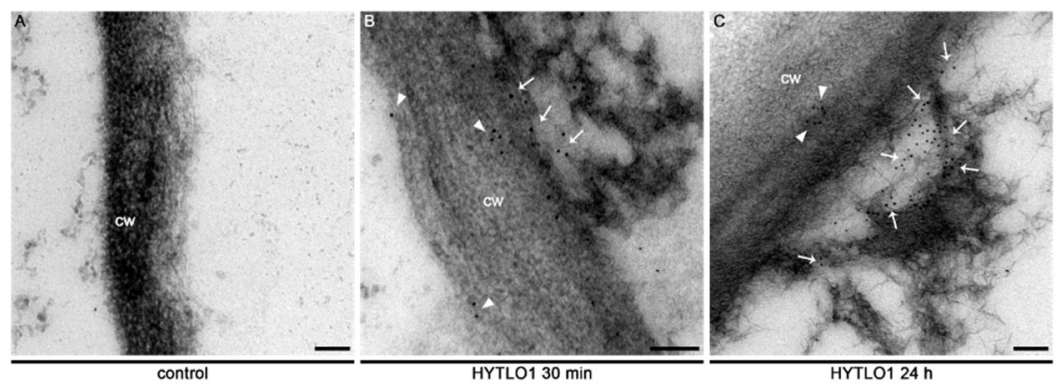

Figure 6. Immunocytochemical analysis of L. japonicus cells treated with HYTLO1. Cells were incubated: (A) in control conditions; (B) with HYTLO1 $(0.6 \mu \mathrm{M})$ for $30 \mathrm{~min}$; (C) with HYTLO1 $(0.6 \mu \mathrm{M})$ for $24 \mathrm{~h}$. Immunogold labelling was carried out by incubation with an affinity-purified anti-HYTLO1 antibody followed by a secondary antibody conjugated with $10 \mathrm{~nm}$ diameter-gold particles. Immunogold-labelled particles are visible at the external surface (arrows) and across the plant cell wall (arrowheads). cw, cell wall. Bars, $100 \mathrm{~nm}$. 
In agreement with cell viability data (Figure 3), transmission electron microscopy (TEM) analyses demonstrated that the ultrastructural organization of L. japonicus cells was well preserved after $24 \mathrm{~h}$ treatment with HYTLO1 (Figure 7).

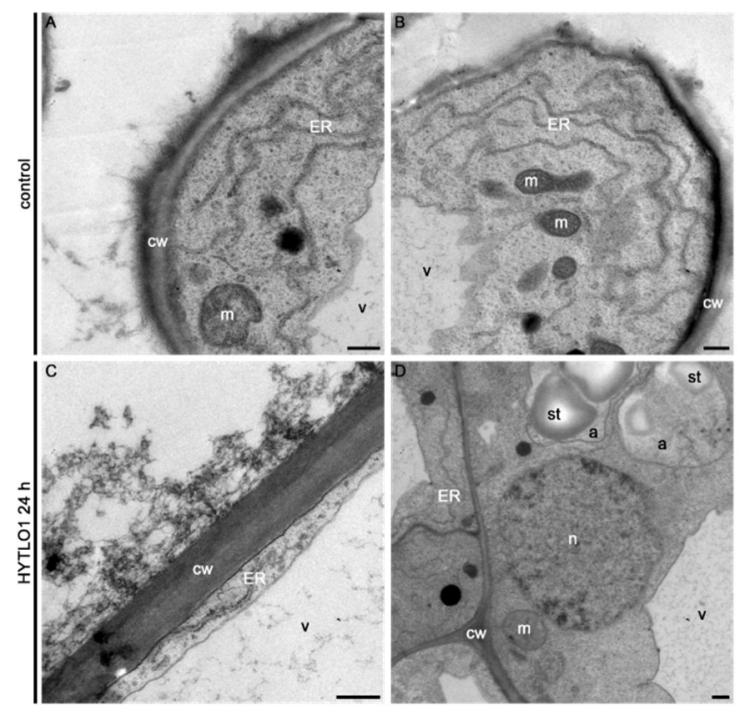

Figure 7. Electron microscopy observations of HYTLO1-treated L. japonicus cells. Cells were incubated: $(\mathbf{A}, \mathbf{B})$ in control conditions; $(\mathbf{C}, \mathbf{D})$ in the presence of HYTLO1 $(0.6 \mu \mathrm{M})$ for $24 \mathrm{~h}$. The ultrastructure of cells was found to be well-preserved even after $24 \mathrm{~h}$ treatment with the fungal hydrophobin. a, amyloplasts; cw, cell wall; ER, endoplasmic reticulum; m, mitochondria; n, nucleus; st, starch granules; v, vacuole. Bars, $500 \mathrm{~nm}$.

\section{Discussion}

Hydrophobins are small molecular weight proteins that play multiple roles in the cell biology of filamentous fungi [46]. In particular, during the early phases of plant-fungus interactions they may play an important function by mediating adhesion to the root surface [21]. Nevertheless, their potential role as elicitors of plant defence responses has been relatively little investigated so far.

In this work we have demonstrated that HYTLO1, a hydrophobin abundantly secreted by the biocontrol fungus Trichoderma longibrachiatum, is perceived in a $\mathrm{Ca}^{2+}$-dependent manner by L. japonicus suspension-cultured cells by inducing a fast, transient $\left[\mathrm{Ca}^{2+}\right]_{\mathrm{cyt}}$ (Figure $1 \mathrm{~A}$ ) and the subsequent activation of genes commonly considered as hallmarks of plant defence responses (Figure 2A-C). Unlike complex metabolite mixtures isolated from Trichoderma culture filtrates, which have been previously shown to cause programmed cell death in soybean cell cultures [9], no reduction in cell viability or ultrastructural alterations were observed after treatment of L. japonicus cells with HYTLO1 (Figures 3 and 7). On the other hand, our data suggest that the fungal hydrophobin acts as a mild proteinaceous elicitor, which may be able to pre-alert plant defence prior to a potential subsequent attack by a real pathogen—a mechanism commonly defined as "priming" [47].

Negative staining of preparations of pure HYTLO1 suggested the assembly of the protein in monolayers (Figure S4), that may help the fungus break the air-water interface during the early stages of plant-fungus interactions. Indeed, the peculiar physical features of these fungal proteins [48] have recently attracted a great deal of interest in view of their potential biotechnological applications as natural surfactants [49]. Unlike other hydrophobins, such as HYDPt-1 from the basidiomycete Pisolithus tinctorius that is exclusively located at the surface of fungal hyphae [50], HYTLO1 is secreted by T. longibrachiatum strain MK1 and interacts with the plant cell surface, as demonstrated by immunofluorescence (Figure S5) and immunogold labelling experiments (Figure 6 and Figure S6) with a specific antibody raised against the purified native protein. 
The research work previously carried out by Lopez-Gomez et al. [51] in the same model legume L. japonicus highlighted the complex interplay of defence responses and symbiotic signalling pathways. Indeed, the notion that boundaries between pathogenesis and symbiosis are subtle and fluid is rapidly emerging [52]. Consistently, the Ljsym4-2 mutant, which is characterized by an early block of the common symbiotic signalling pathway induced by both Myc factors and Nod factors, has shown altered gene expression profiles both in control conditions and after treatment with different biotic stimuli in several additional studies $[53,54]$.

The new experimental system set up in this work, given by aequorin-expressing suspensioncultured cells of L. japonicus, derived from both wild-type and Ljsym4-2 mutant, can be a useful tool to analyse $\mathrm{Ca}^{2+}$ signalling events not only during the beneficial interaction with an avirulent symbiont, such as the biocontrol fungus Trichoderma [7], but also in the establishment of symbioses with rhizobia and AM fungi. The Ljsym4-2 mutant is defective in the CASTOR gene encoding for a $\mathrm{K}^{+}$-permeable channel that has been clearly demonstrated to be an essential modulator of the $\mathrm{Ca}^{2+}$ spiking phenomenon originating in the nuclear and perinuclear region of legume cortical cells in response to endosymbiotic microbes $[39,41,55,56]$. The molecular identity of the nuclear-localized $\mathrm{Ca}^{2+}$ channels responsible for symbiotic $\mathrm{Ca}^{2+}$ oscillations has recently been unravelled [40]. Indeed, when the two L. japonicus cell lines were challenged with the microbial symbiotic molecules Myc factors and Nod factors, the $\left[\mathrm{Ca}^{2+}\right]_{\mathrm{cyt}}$ traces observed in the wild-type and mutant cell lines were clearly different, i.e., the Ljsym4-2 lacked the second flattened $\mathrm{Ca}^{2+}$ increase occurring after about $15 \mathrm{~min}$ (Figure 1B,C). This differential $\mathrm{Ca}^{2+}$ response is likely due to the lack of the asynchronous cytosolic $\mathrm{Ca}^{2+}$ oscillations, stemming from the controlled $\mathrm{Ca}^{2+}$ release/uptake by the nuclear envelope in the mutant cell population, when compared to the wild-type $[39,57,58]$. On the other hand, the trace and kinetics of the cytosolic $\mathrm{Ca}^{2+}$ change triggered by the hydrophobin was found to be very similar in wild-type and Ljsym4-2 mutant cell lines (Figure 1A). This was generally true also for the changes of expression of genes involved in plant defence (Figure 2 and Figure S2). These results indicate possible differences in the signalling transduction pathways triggered by factors secreted by different symbiotic partners, which can be consistent with the versatility of plant receptor-like kinases (RLKs) involved in the response to microbial signals [59]. On the basis of our TEM analyses of an HYTLO1-derived web-like network at the plant cell surface, we may hypothesize that the observed intracellular $\mathrm{Ca}^{2+}$ elevation and change in defence gene expression can originate, at least in part, by a mechanical stimulation exerted by the fungal biofilm. Mechanical stimuli generate $\mathrm{Ca}^{2+}$ signals in plants, and the specific plant mechanosensing mechanisms are biological processes that have recently attracted the attention of different research groups $[60,61]$. Moreover, it has been demonstrated that plant perception of soft mechanical stress can activate defence responses [62]. However, TEM observations of HYTLO1-treated L. japonicus cultured cells favoured the possibility that the 7.2 kDa hydrophobin [20] may also permeate the apoplastic compartment (Figure 6 and Figure S6), possibly interacting with the plasma membrane. Indeed, Trichoderma secretes in vivo a battery of cell wall degrading enzymes [63], which may further facilitate the access of secreted molecules, and then HYTLO1, to specific binding sites at the plasma membrane level. Further work will be required to identify potential receptors for hydrophobins.

The pharmacological approach used in this work suggests that HYTLO1 triggers both a $\mathrm{Ca}^{2+}$ influx from the extracellular milieu, as well as a $\mathrm{Ca}^{2+}$ release from a NAADP-sensitive intracellular $\mathrm{Ca}^{2+}$ store. NAADP is a pyridine nucleotide derivative that in the last two decades has been increasingly demonstrated to act as a potent $\mathrm{Ca}^{2+}$ mobilizing agent in animal cells, in addition to the well-established intracellular messenger inositol 1,4,5-trisphosphate $\left(\mathrm{InsP}_{3}\right)$ and cyclic ADP-ribose (cADPR) [28]. Although NAADP has been shown to trigger $\mathrm{Ca}^{2+}$ release also in higher plants [29], its involvement in plant physiological events had yet to emerge. By using Ned-19, a newly-developed chemical probe for NAADP [27], a NAADP-gated $\mathrm{Ca}^{2+}$ release was shown to occur in response to copper excess in the marine alga Ulva compressa [30], as well as in the brown alga Ectocarpus siliculosus [31]. These data suggest that the spectrum of photosynthetic organisms responsive to NAADP might be broader than previously envisaged. The results obtained in this work confirm that Ned-19 can be used as 
a valuable tool to investigate NAADP-mediated $\mathrm{Ca}^{2+}$ signalling and highlight the participation of NAADP in a plant response to a biotic stimulus (a fungal proteinaceous elicitor). Interestingly, whereas members of the two-pore channel (TPC) gene family have been demonstrated to encode NAADP receptors in acidic organelles (endo-lysosomes) of animal cells (see [64,65] for review), the identity of NAADP receptors in plant cells still remain elusive. TPC1, the only member of the TPC gene family in A. thaliana, has been shown to encode the slow-vacuolar (SV) channel, a $\mathrm{Ca}^{2+}$-permeable channel located at the vacuolar membrane [66] and regulated by voltage and $\mathrm{Ca}^{2+}$ (see [67-69] for review). Interestingly, NAADP was found to be completely ineffective in the activation of TPC1, as well as of other tonoplast cation channels [70]. Indeed, early biochemical studies, consisting in ${ }^{45} \mathrm{Ca}^{2+}$ release assays on sucrose-fractionated membrane vesicles, indicated an endoplasmic reticulum (ER)-localization for NAADP-gated $\mathrm{Ca}^{2+}$ release [29]. Interestingly, the recently reported crystal structure of $A$. thaliana TPC1 highlighted the presence of a Ned-19 binding site [71], suggesting the potential ability of this pharmacophore to allosterically block the channel activation. However, Ned-19 does not interact with the functionally-relevant voltage sensor [72]. Future in depth-studies will be necessary to further investigate the intracellular localization and additional physiological roles of plant NAADP receptors.

\section{Materials and Methods}

\subsection{Chemicals}

The hydrophobin HYTLO1 was isolated and purified to homogeneity from in vitro cultures of the biocontrol strain MK1 of Trichoderma longibrachiatum, as described by Ruocco et al. [20]. The pure protein was dissolved in 50\% ethanol. Crude Myc factors were obtained by collecting the exudates of germinated spores of the arbuscular mycorrhizal fungus Gigaspora margarita (kindly provided by Paola Bonfante, Torino, Italy), lyophilizing and resuspending them in cell culture medium prior to cell treatment, as previously described [57]. Crude Nod factors extracted from Mesorhizobium loti were kindly provided by Makoto Hayashi (Yokohama, Japan). All chemicals used in the pharmacological analysis of $\mathrm{Ca}^{2+}$ fluxes (EGTA, $\mathrm{LaCl}_{3}$, nicotinamide) were obtained from Sigma-Aldrich (St. Louis, MO, USA), except trans-Ned-19, that was purchased from ENZO Life Sciences (Farmingdale, New York, USA).

\subsection{Plant Material}

Lotus japonicus (ecotype Gifu) wild-type and sym4-2 mutant seeds, defective in CASTOR, were kindly provided by J. Stougaard (Aarhus, Denmark) and M. Parniske (Munich, Germany), respectively.

\subsection{Molecular Cloning and L. japonicus Transformation Procedures}

To obtain the aequorin-expressing T-DNA construct, the aequorin cDNA was excised from the cytAEQ plasmid [73] by SmaI digestion. The $600 \mathrm{bp} S m a \mathrm{I}$ fragment was subcloned into the pSE380 plasmid (Thermo Fisher Scientific, Waltham, MA, USA) in order to gain additional restriction sites for the next step of subcloning. A BglII-SalI fragment was then ligated between a CaMV-35S promoter sequence and a tNOS terminator into pCAMBIA1300 [33] BglII-SalI double digested to obtain the pAB1 T-DNA construct (Figure S1A).

Agrobacterium tumefaciens-mediated L. japonicus transformation was performed as previously described [34,35]. Primary transformed plants of both wild-type and Ljsym4-2 symbiotic mutant lines were selected on $5 \mu \mathrm{g} / \mathrm{mL}$ hygromicin B-containing medium and allowed to self-pollinate. Successful transformation and expression of the construct was confirmed by RT-PCR analysis of aequorin gene expression. Selected T2 homozygous plants (Figure S1B) were used to set up in vitro cell cultures. 


\subsection{Establishment of Aequorin-Expressing L. japonicus Cell Cultures}

Aequorin-expressing cell cultures were set up by in vitro dedifferentiation of hypocotyls from transgenic $L$. japonicus seedlings. Briefly, hypocotyl explants from 8-day-old axenically grown seedlings were transferred on agarized $(0.8 \%, w / v)$ Callus Induction Medium (CIM, $3.2 \mathrm{~g} / \mathrm{L}$ Gamborg B5 basal medium, $0.5 \mathrm{~g} / \mathrm{L}$ MES, $2 \%(w / v)$ sucrose, $0.5 \mu \mathrm{g} / \mathrm{mL}$ 2,4-dichlorophenoxyacetic acid (2,4-D), $0.05 \mu \mathrm{g} / \mathrm{mL}$ kinetin), supplemented with $5 \mu \mathrm{g} / \mathrm{mL}$ hygromycin B. After two subculturing steps, well-developed calli were transferred in Gamborg B5 liquid medium, $\mathrm{pH} 5.5$, containing $2 \%(w / v)$ sucrose, $2 \mu \mathrm{g} / \mathrm{mL}$ 2,4-D, $5 \mu \mathrm{g} / \mathrm{mL}$ hygromycin B. Suspension-cultured cells were maintained at $24{ }^{\circ} \mathrm{C}$ on a rotary shaker at $80 \mathrm{rpm}$ under $16 \mathrm{~h}$ light $/ 8 \mathrm{~h}$ dark photoperiod. They were subcultured weekly by inoculating $1 \mathrm{~mL}$ packed cell volume into $20 \mathrm{~mL}$ fresh cell culture medium with, as described by Moscatiello et al. [37].

\subsection{Cell Treatments}

Exponentially-growing cells (five days) were treated with purified HYTLO1 $(0.6 \mu \mathrm{M})$. The dose applied to cells was chosen on the basis of previous work concerning in vivo bioassays of physiological effects of HYTLO1 on plants [20]. In some experiments cells were treated with crude preparations of Myc factors or Nod factors. The final dose applied to cells corresponded to 10-fold concentrated AM fungal exudates and $1 \mu \mathrm{M}$ Nod factors. In this latter case, suspension-cultured cells were grown in low nitrogen medium (containing $5 \mathrm{mM} \mathrm{KNO}_{3}$ ) for two days prior to the onset of the $\mathrm{Ca}^{2+}$ measurement assays.

\subsection{Aequorin-Based $\mathrm{Ca}^{2+}$ Measurements}

Aequorin was reconstituted by overnight incubation of mid-exponential phase transgenic L. japonicus cell cultures with $5 \mu \mathrm{M}$ coelenterazine (Prolume, Pinetop, AZ, USA) in darkness. Cells were then extensively washed with fresh culture medium and allowed to recover from the touch response for at least $15 \mathrm{~min}$. Aequorin-based $\mathrm{Ca}^{2+}$ measurements were performed as recently described [38], by using $100 \mu \mathrm{L}$ of reconstituted cell suspension culture (containing about $5 \mathrm{mg}$ cells, fresh weight). For pharmacological studies, cells were pre-incubated with the appropriate inhibitor for $10 \mathrm{~min}$ $\left(\mathrm{LaCl}_{3}\right)$ or $30 \mathrm{~min}$ (Ned-19, nicotinamide). For experiments carried out in the absence of extracellular $\mathrm{Ca}^{2+}$, cells were extensively washed with $\mathrm{Ca}^{2+}$-free culture medium and then resuspended in the same medium containing $600 \mu \mathrm{M}$ EGTA. In the case of molecules dissolved in ethanol (HYTLO1) or DMSO (Ned-19), control cells were treated with the same percentage (maximum $0.5 \%, v / v$ ) of the organic solvent.

\subsection{Immunofluorescence, Immunocytochemisty, and TEM Analyses}

Immunofluorescence experiments were performed on L. japonicus suspension cultured cells as described by Zonin et al. [74]. Labelling was carried out by using affinity-purified polyclonal antibodies raised against purified native HYTLO1 (ProteoGenix, Schiltigheim, France), diluted 1:100, followed by Alexa Fluor 594 goat anti-rabbit IgG (Thermo Fisher Scientific). Working concentrations and specificity of the primary antibody were assessed in Western blot experiments against purified HYTLO1 and crude protein extracts from L. japonicus cells.

TEM analyses were performed as described by Tagu et al. [50]. Immunogold labelling (dilution 1:100) was performed as recently described [75]. Samples were observed with a Tecnai 12-BT transmission electron microscope (FEI, Eindhoven, The Netherlands) operating at $120 \mathrm{kV}$ equipped with a Tietz camera.

For negative staining, purified HYTLO1 $(0.6 \mu \mathrm{M})$ was adsorbed on carbon-coated EM grids, washed and stained on a drop of $1 \%$ uranyl acetate solution. 


\subsection{Gene Expression Analyses}

For the screening of primary T1 transformants, total RNA was prepared from leaves of two week-old L. japonicus plants by the procedure reported by Kistner and Matamoros [76] and reversed-transcribed as described below. The oligonucleotides used for the PCR amplification are Aeq-for 5'-GCAAGCCAAACGACACAAAG-3'; Aeq-rev 5'-GAACCAACGCTCATCCGTAT-3'. The amplified $162 \mathrm{bp}$ aequorin fragment was inserted in pCR2.1 cloning vector (Thermo Fisher Scientific) and confirmed by sequencing. The PCR program used was as follows: $94{ }^{\circ} \mathrm{C}$ for $5 \mathrm{~min}$ and 30 cycles of $94{ }^{\circ} \mathrm{C}$ for $30 \mathrm{~s}$, $58{ }^{\circ} \mathrm{C}$ for $30 \mathrm{~s}$, and $72{ }^{\circ} \mathrm{C}$ for $30 \mathrm{~s}$. The ubiquitin gene (UBI, AW719589) was used as an internal standard to normalize expression levels ( 25 cycles of amplification; UBI-F-1 5'-TTCACCTTGTGCTCCGTCTTC-3'; UBI-R-1 5'-AACAACAGCACACACAGACAATCC-3').Semi-quantitative RT-PCR analyses of defence gene expression in L. japonicus cell suspension cultures incubated in control conditions or after treatment with HYTLO1 were performed as recently described [75]. The defence-related genes encoding for the following proteins were chosen: MPK3, an enzyme frequently activated in signal transduction cascades in response to phytopathogens [77]; CP450, an enzyme involved in a wide range of biosynthetic reactions, including the synthesis of phytoalexins [78]; WRKY33, a transcriptional regulator involved in a large array of defence responses [79,80]; PR1, which expression is induced by many pathogens, and considered as a molecular marker of systemic acquired resistance (SAR) $[81,82]$. Transcript levels were normalized to ATP synthase [51]. The oligonucleotide primers were as described by [51] for LjMPK3, LjWRKY33, LjCP450, and LjATPsyn, and by [53] for LjPR1. The number of cycles exploited for a linear range of gene amplification in the RT-PCR reactions was experimentally determined. Densitometric analysis of agarose gels stained with $0.5 \mu \mathrm{g} / \mathrm{mL}$ ethidium bromide was carried out with the Quantity One software (Bio-Rad, Hercules, CA, USA). RT-PCR experiments were conducted in triplicate on at least three independent experiments.

Quantitative reverse transcription PCR, used to validate the data, was performed in $10 \mu \mathrm{L}$ using HOT FIREPol EvaGreen qPcr Mix Plus (Solys BioDyne, Tartu, Estonia) and $2.5 \mathrm{ng}$ of the different cDNA template. Three replicates were performed for each reaction. The qPCR reaction was conducted in a 7500 Real-Time PCR System (Thermo Fisher) according to the following cycle: $95^{\circ} \mathrm{C}$ for $12 \mathrm{~min}$; $95^{\circ} \mathrm{C}$ for $15 \mathrm{~s}, 59^{\circ} \mathrm{C}$ for $20 \mathrm{~s}$, for 40 cycles. Differences in the target genes expression were evaluated by a relative quantification method normalizing the data to the endogenous reference gene LjATPsyn.

\subsection{Cell Viability}

Cell viability, after treatment for HYTLO1 for different time intervals, in the absence or presence of $\mathrm{Ca}^{2+}$ chelating agents $/ \mathrm{Ca}^{2+}$ channel inhibitors, was determined by the Evans Blue method [42].

\subsection{Statistical Analysis}

Data are expressed as mean \pm SE. The statistical significance of differences $(P<0.05)$ between means was evaluated using the Student's $t$ test.

Supplementary Materials: Supplementary materials can be found at http:/ / www.mdpi.com/1422-0067/19/9/ 2596/s1.

Author Contributions: R.M. set up L. japonicus cell cultures, performed $\mathrm{Ca}^{2+}$ measurements, gene expression analyses, analysed the data, and prepared the figures, with help from S.S., E.C., and S.N. M.R. purified HYTLO1 from T. longibrachiatum MK1 culture medium used for all the experiments and for antibody production. A.B. and M.C. designed the aequorin expression plasmid and generated L. japonicus transgenic lines. B.B. and L.N. performed TEM analyses. M.R., B.B., M.C., P.M., and M.L. contributed to discussion of the results and assisted in article editing. L.N. conceived the research, designed the experiments, and wrote the paper. All authors read and approved the final manuscript.

Funding: This research was funded by Dotazione Ordinaria della Ricerca Dipartimentale (DOR) 2016-2018 to L.N. and Programmi di Ricerca Scientifica di Rilevante Interesse Nazionale (PRIN) to M.L., L.N., and M.C. 
Acknowledgments: We thank J. Stougaard (Aarhus, Denmark) and M. Parniske (Munich, Germany) for the kind gift of L. japonicus wild-type and sym4-2 mutant seeds, respectively. We are grateful to M. Brini (Padova, Italy), P. Bonfante (Torino, Italy) and M. Hayashi (Yokohama, Japan) for kindly providing the cytAEQ plasmid, G. margarita spores and M. loti Nod factors, respectively. We also thank S. Marcato and the Electron Microscopy Service of the Department of Biology (Padova, Italy) for skilful technical assistance.

Conflicts of Interest: The authors declare no conflict of interest.

$\begin{array}{ll}\text { Abbreviations } \\ \mathrm{Ca}^{2+} & \text { Calcium } \\ \text { cADPR } & \text { Cyclic ADP-ribose } \\ \text { 2,4-D } & \text { Dichlorophenoxyacetic acid } \\ \text { EGTA } & \text { Ethylene glycol-bis( } \beta \text {-aminoethyl ether })-N, N, N^{\prime}, N^{\prime} \text {-tetraacetic acid } \\ \text { NAADP } & \text { Nicotinic acid adenine dinucleotide phosphate } \\ \text { TEM } & \text { Transmission electron microscopy } \\ \text { TPC } & \text { Two-pore channel }\end{array}$

\section{References}

1. Brotman, Y.; Kapuganti, J.G.; Viterbo, A. Trichoderma. Curr. Biol. 2010, 20, R390-R391. [CrossRef] [PubMed]

2. Harman, G.E.; Herrera-Estrella, A.H.; Horwitz, B.A.; Lorito, M. Special issue: Trichoderma-From basic Biology to Biotechnology. Microbiology 2012, 158, 1-2. [CrossRef] [PubMed]

3. Hermosa, R.; Viterbo, A.; Chet, I.; Monte, E. Plant-beneficial effects of Trichoderma and of its genes. Microbiology 2012, 158, 17-25. [CrossRef] [PubMed]

4. Woo, S.L.; Ruocco, M.; Vinale, F.; Nigro, M.; Marra, R.; Lombardi, N.; Pascale, A.; Lanzuise, S.; Manganiello, G.; Lorito, M. Trichoderma-based products and their widespread use in agriculture. Open Mycol. J. 2014, 8, 71-126. [CrossRef]

5. López-Bucio, J.; Pelagio-Flores, R.; Herrera-Estrella, A. Trichoderma as biostimulant: Exploiting the multilevel properties of a plant beneficial fungus. Sci. Hortic. 2015, 196, 109-123. [CrossRef]

6. Druzhinina, I.S.; Seidl-Seiboth, V.; Herrera-Estrella, A.; Horwitz, B.A.; Kenerley, C.M.; Monte, E.; Mukherjee, P.K.; Zeilinger, S.; Grigoriev, I.V.; Kubicek, C.P. Trichoderma: The genomics of opportunistic success. Nat. Rev. Microbiol. 2011, 9, 749-759. [CrossRef] [PubMed]

7. Harman, G.E.; Howell, C.R.; Viterbo, A.; Chet, I.; Lorito, M. Trichoderma species-Opportunistic, avirulent plant symbionts. Nat. Rev. Microbiol. 2004, 2, 43-56. [CrossRef] [PubMed]

8. Woo, S.L.; Scala, F.; Ruocco, M.; Lorito, M. The Molecular Biology of the interactions between Trichoderma spp., phytopathogenic fungi, and plants. Phytopathology 2006, 96, 181-185. [CrossRef] [PubMed]

9. Navazio, L.; Baldan, B.; Moscatiello, R.; Zuppini, A.; Woo, S.L.; Mariani, P.; Lorito, M. Calcium-mediated perception and defense responses activated in plant cells by metabolite mixtures secreted by the biocontrol fungus Trichoderma atroviride. BMC Plant Biol. 2007, 7, 41. [CrossRef] [PubMed]

10. Vinale, F.; Sivasithamparam, K.; Ghisalberti, E.L.; Marra, R.; Woo, S.L.; Lorito, M. Trichoderma-plantpathogen interactions. Soil Biol. Biochem. 2008, 40,1-10. [CrossRef]

11. Clapham, D.E. Calcium signaling. Cell 2007, 131, 1047-1058. [CrossRef] [PubMed]

12. Dodd, A.N.; Kudla, J.; Sanders, D. The language of calcium signaling. Annu. Rev. Plant Biol. 2010, 61, 593-620. [CrossRef] [PubMed]

13. Cai, X.; Clapham, D.E. Ancestral $\mathrm{Ca}^{2+}$ signaling machinery in early animal and fungal evolution. Mol. Biol. Evol. 2012, 29, 91-100. [CrossRef] [PubMed]

14. Domínguez, D.C.; Guragain, M.; Patrauchan, M. Calcium binding proteins and calcium signaling in prokaryotes. Cell Calcium 2015, 57, 151-165. [CrossRef] [PubMed]

15. Aldon, D.; Mbengue, M.; Mazars, C.; Galaud, J.P. Calcium signalling in plant biotic interactions. Int. J. Mol. Sci. 2018, 19, 665. [CrossRef] [PubMed]

16. Kudla, J.; Becker, D.; Grill, E.; Hedrich, R.; Hippler, M.; Kummer, U.; Parniske, M.; Romeis, T.; Schumacher, K. Advances and current challenges in calcium signaling. New Phytol. 2018, 218, 414-431. [CrossRef] [PubMed]

17. Costa, A.; Navazio, L.; Szabo, I. The contribution of organelles to plant intracellular calcium signalling. J. Exp. Bot. 2018, 69, 4175-4193. [CrossRef] [PubMed] 
18. Zipfel, C.; Oldroyd, G.E. Plant signalling in symbiosis and immunity. Nature 2017, 543, 328-336. [CrossRef] [PubMed]

19. Lecourieux, D.; Ranjeva, R.; Pugin, A. Calcium in plant defence-signalling pathways. New Phytol. 2006, 171, 249-269. [CrossRef] [PubMed]

20. Ruocco, M.; Lanzuise, S.; Lombardi, N.; Woo, S.L.; Vinale, F.; Marra, R.; Varlese, R.; Manganiello, G.; Pascale, A.; Scala, V.; et al. Multiple roles and effects of a novel Trichoderma hydrophobin. Mol. Plant Microbe Interact. 2015, 28, 167-179. [CrossRef] [PubMed]

21. Whiteford, J.R.; Spanu, P.D. Hydrophobins and the interactions between fungi and plants. Mol. Plant Pathol. 2002, 3, 391-400. [CrossRef] [PubMed]

22. Guzmán-Guzmán, P.; Alemán-Duarte, M.I.; Delaye, L.; Herrera-Estrella, A.; Olmedo-Monfil, V. Identification of effector-like proteins in Trichoderma spp. and role of a hydrophobin in the plant-fungus interaction and mycoparasitism. BMC Genet. 2017, 18, 16. [CrossRef] [PubMed]

23. Przylucka, A.; Akcapinar, G.B.; Chenthamara, K.; Cai, F.; Grujic, M.; Karpenko, J.; Livoi, M.; Shen, Q.; Kubicek, C.P.; Druzhinina, I.S. HFB7-A novel orphan hydrophobin of the Harzianum and Virens clades of Trichoderma, is involved in response to biotic and abiotic stresses. Fungal Genet. Biol. 2017, 102, 63-76. [CrossRef] [PubMed]

24. Viterbo, A.; Chet, I. TasHyd1, a new hydrophobin gene from the biocontrol agent Trichoderma asperellum, is involved in plant root colonization. Mol. Plant Pathol. 2006, 7, 249-258. [CrossRef] [PubMed]

25. Kurt, H.; Jens, S. Lotus japonicus, an autogamous, diploid legume species for classical and molecular genetics. Plant J. 1992, 2, 487-496.

26. Jiang, Q.; Gresshoff, P.M. Classical and molecular genetics of the model legume Lotus japonicus. Mol. Plant Microbe Interact. 1997, 10, 59-68. [CrossRef] [PubMed]

27. Naylor, E.; Arredouani, A.; Vasudevan, S.R.; Lewis, A.M.; Parkesh, R.; Mizote, A.; Rosen, D.; Thomas, J.M.; Izumi, M.; Ganesan, A.; et al. Identification of a chemical probe for NAADP by virtual screening. Nat. Chem. Biol. 2009, 5, 220-226. [CrossRef] [PubMed]

28. Galione, A.; Morgan, A.J.; Arredouani, A.; Davis, L.C.; Rietdorf, K.; Ruas, M.; Parrington, J. NAADP as an intracellular messenger regulating lysosomal calcium-release channels. Biochem. Soc. Trans. 2010, 38, 1424-1431. [CrossRef] [PubMed]

29. Navazio, L.; Bewell, M.A.; Siddiqua, A.; Dickinson, G.D.; Galione, A.; Sanders, D. Calcium release from the endoplasmic reticulum of higher plants elicited by the NADP metabolite nicotinic acid adenine dinucleotide phosphate. Proc. Natl. Acad. Sci. USA 2000, 97, 8693-8698. [CrossRef] [PubMed]

30. González, A.; Cabrera Mde, L.; Henríquez, M.J.; Contreras, R.A.; Morales, B.; Moenne, A. Cross talk among calcium, hydrogen peroxide, and nitric oxide and activation of gene expression involving calmodulins and calcium-dependent protein kinases in Ulva compressa exposed to copper excess. Plant Physiol. 2012, 158, 1451-1462. [CrossRef] [PubMed]

31. González, A.; Sáez, C.A.; Moenne, A. Copper-induced activation of TRPs and VDCCs triggers a calcium signature response regulating gene expression in Ectocarpus siliculosus. PeerJ. 2018, 6, e4556. [CrossRef] [PubMed]

32. Mun, T.; Bachmann, A.; Gupta, V.; Stougaard, J.; Andersen, S.U. Lotus Base: An integrated information portal for the model legume Lotus japonicus. Sci. Rep. 2016, 6, 39447. [CrossRef] [PubMed]

33. Hajdukiewicz, P.; Svab, Z.; Maliga, P. The small, versatile $p P Z P$ family of Agrobacterium binary vectors for plant transformation. Plant Mol. Biol. 1994, 25, 989-994. [CrossRef] [PubMed]

34. Lombari, P.; Ercolano, E.; El Alaoui, H.; Chiurazzi, M. A new transformation-regeneration procedure in the model legume Lotus japonicus: Root explants as a source of large numbers of cells susceptible to Agrobacterium-mediated transformation. Plant Cell Rep. 2003, 21, 771-777. [PubMed]

35. Barbulova, A.; D'Apuzzo, E.; Rogato, A.; Chiurazzi, M. Improved procedures for in vitro regeneration and for phenotypic analysis in the model legume Lotus japonicus. Funct. Plant Biol. 2005, 32, 529-536. [CrossRef]

36. Bonfante, P.; Genre, A.; Faccio, A.; Martini, I.; Schauser, L.; Stougaard, J.; Webb, J.; Parniske, M. The Lotus japonicus LjSym4 gene is required for the successful symbiotic infection of root epidermal cells. Mol. Plant Microbe Interact. 2000, 13, 1109-1120. [CrossRef] [PubMed]

37. Moscatiello, R.; Baldan, B.; Navazio, L. Plant cell suspension cultures. Methods Mol. Biol. 2013, 953, 77-93. [PubMed] 
38. Sello, S.; Perotto, J.; Carraretto, L.; Szabò, I.; Vothknecht, U.C.; Navazio, L. Dissecting stimulus-specific Ca ${ }^{2+}$ signals in amyloplasts and chloroplasts of Arabidopsis thaliana cell suspension cultures. J. Exp. Bot. 2016, 67, 3965-3974. [CrossRef] [PubMed]

39. Charpentier, M.; Bredemeier, R.; Wanner, G.; Takeda, N.; Schleiff, E.; Parniske, M. Lotus japonicus CASTOR and POLLUX are ion channels essential for perinuclear calcium spiking in legume root endosymbiosis. Plant Cell 2008, 20, 3467-3479. [CrossRef] [PubMed]

40. Charpentier, M.; Sun, J.; Vaz Martins, T.; Radhakrishnan, G.V.; Findlay, K.; Soumpourou, E.; Thouin, J.; Véry, A.A.; Sanders, D.; Morris, R.J.; et al. Nuclear-localized cyclic nucleotide-gated channels mediate symbiotic calcium oscillations. Science 2016, 352, 1102-1105. [CrossRef] [PubMed]

41. Venkateshwaran, M.; Cosme, A.; Han, L.; Banba, M.; Satyshur, K.A.; Schleiff, E.; Parniske, M.; Imaizumi-Anraku, H.; Ané, J.M. The recent evolution of a symbiotic ion channel in the legume family altered ion conductance and improved functionality in calcium signaling. Plant Cell 2012, 24, 2528-2545. [CrossRef] [PubMed]

42. Baker, C.J.; Mock, N.M. An improved method for monitoring cell death in cell suspension and leaf disc assays using evans blue. Plant Cell Tissue Organ Cult. 1994, 39, 7-12. [CrossRef]

43. Knight, H.; Trewavas, A.J.; Knight, M.R. Calcium signalling in Arabidopsis thaliana responding to drought and salinity. Plant J. 1997, 12, 1067-1078. [CrossRef] [PubMed]

44. Abdul-Awal, S.M.; Hotta, C.T.; Davey, M.P.; Dodd, A.N.; Smith, A.G.; Webb, A.A. NO-Mediated $\left[\mathrm{Ca}^{2+}\right]_{\mathrm{cyt}}$ increases depend on ADP-ribosyl cyclase activity in Arabidopsis. Plant Physiol. 2016, 171, 623-631. [CrossRef] [PubMed]

45. Lin, W.K.; Bolton, E.L.; Cortopassi, W.A.; Wang, Y.; O’Brien, F.; Maciejewska, M.; Jacobson, M.P.; Garnham, C.; Ruas, M.; Parrington, J.; et al. Synthesis of the $\mathrm{Ca}^{2+}$-mobilizing messengers NAADP and cADPR by intracellular CD38 enzyme in the mouse heart: Role in beta-adrenoceptor signaling. J. Biol. Chem. 2017, 292, 13243-13257. [CrossRef] [PubMed]

46. Wosten, H.A. Hydrophobins: Multipurpose proteins. Annu. Rev. Microbiol. 2001, 55, 625-646. [CrossRef] [PubMed]

47. Prime-A-Plant Group; Conrath, U.; Beckers, G.J.; Flors, V.; García-Agustín, P.; Jakab, G.; Mauch, F.; Newman, M.A.; Pieterse, C.M.; Poinssot, B.; et al. Priming: Getting ready for battle. Mol. Plant Microbe Interact. 2006, 19, 1062-1071. [CrossRef] [PubMed]

48. Sunde, M.; Kwan, A.H.; Templeton, M.D.; Beever, R.E.; Mackay, J.P. Structural analysis of hydrophobins. Micron 2008, 39, 773-784. [CrossRef] [PubMed]

49. Cox, P.W.; Hooley, P. Hydrophobins: New prospects for biotechnology. Fungal Biol. Rev. 2009, $23,40-47$. [CrossRef]

50. Tagu, D.; De Bellis, R.; Balestrini, R.; De Vries, O.M.H.; Piccoli, G.; Stocchi, V.; Bonfante, P.; Martin, F. Immunolocalization of hydrophobin HYDPt-1 from the ectomycorrhizal basidiomycete Pisolithus tinctorius during colonization of Eucalyptus globulus roots. New Phytol. 2001, 149, 127-135. [CrossRef]

51. Lopez-Gomez, M.; Sandal, N.; Stougaard, J.; Boller, T. Interplay of flg22-induced defence responses and nodulation in Lotus japonicus. J. Exp. Bot. 2012, 63, 393-401. [CrossRef] [PubMed]

52. Hacquard, S.; Spaepen, S.; Garrido-Oter, R.; Schulze-Lefert, P. Interplay between innate immunity and the plant microbiota. Annu. Rev. Phytopathol. 2017, 55, 565-589. [CrossRef] [PubMed]

53. Bastianelli, F.; Costa, A.; Vescovi, M.; D’Apuzzo, E.; Zottini, M.; Chiurazzi, M.; Lo Schiavo, F. Salicylic acid differentially affects suspension cell cultures of Lotus japonicus and one of its non-symbiotic mutants. Plant Mol. Biol. 2010, 72, 469-483. [CrossRef] [PubMed]

54. Francia, D.; Chiltz, A.; Lo Schiavo, F.; Pugin, A.; Bonfante, P.; Cardinale, F. AM fungal exudates activate MAP kinases in plant cells in dependence from cytosolic Ca $\left({ }^{2+}\right)$ increase. Plant Physiol. Biochem. 2011, 49, 963-969. [CrossRef] [PubMed]

55. Chabaud, M.; Genre, A.; Sieberer, B.J.; Faccio, A.; Fournier, J.; Novero, M.; Barker, D.G.; Bonfante, P. Arbuscular mycorrhizal hyphopodia and germinated spore exudates trigger $\mathrm{Ca}^{2+}$ spiking in the legume and nonlegume root epidermis. New Phytol. 2011, 189, 347-355. [CrossRef] [PubMed]

56. Sieberer, B.J.; Chabaud, M.; Fournier, J.; Timmers, A.C.; Barker, D.G. A switch in $\mathrm{Ca}^{2+}$ spiking signature is concomitant with endosymbiotic microbe entry into cortical root cells of Medicago truncatula. Plant J. 2012, 69, 822-830. [CrossRef] [PubMed] 
57. Navazio, L.; Moscatiello, R.; Genre, A.; Novero, M.; Baldan, B.; Bonfante, P.; Mariani, P. A diffusible signal from arbuscular mycorrhizal fungi elicits a transient cytosolic calcium elevation in host plant cells. Plant Physiol. 2007, 144, 673-681. [CrossRef] [PubMed]

58. Kosuta, S.; Hazledine, S.; Sun, J.; Miwa, H.; Morris, R.J.; Downie, J.A.; Oldroyd, G.E. Differential and chaotic calcium signatures in the symbiosis signaling pathway of legumes. Proc. Natl. Acad. Sci. USA 2008, 105, 9823-9828. [CrossRef] [PubMed]

59. Antolín-Llovera, M.; Ried, M.K.; Binder, A.; Parniske, M. Receptor kinase signaling pathways in plant-microbe interactions. Annu. Rev. Phytopathol. 2012, 50, 451-473. [CrossRef] [PubMed]

60. Monshausen, G.B.; Haswell, E.S. A force of nature: Molecular mechanisms of mechanoperception in plants. J. Exp. Bot. 2013, 64, 4663-4680. [CrossRef] [PubMed]

61. Kurusu, T.; Kuchitsu, K.; Nakano, M.; Nakayama, Y.; Iida, H. Plant mechanosensing and $\mathrm{Ca}^{2+}$ transport. Trends Plant Sci. 2013, 18, 227-233. [CrossRef] [PubMed]

62. Benikhlef, L.; L'Haridon, F.; Abou-Mansour, E.; Serrano, M.; Binda, M.; Costa, A.; Lehmann, S.; Métraux, J.P. Perception of soft mechanical stress in Arabidopsis leaves activates disease resistance. BMC Plant Biol. 2013, 13, 133. [CrossRef] [PubMed]

63. Markovich, N.A.; Kononova, G.L. Lytic enzymes of Trichoderma and their role in plant defense from fungal diseases: A review. Appl. Biochem. Microbiol. 2003, 39, 341-351. [CrossRef]

64. Galione, A. NAADP receptors. Cold Spring Harb. Perspect. Biol. 2011, 3, a004036. [CrossRef] [PubMed]

65. Morgan, A.J.; Davis, L.C.; Ruas, M.; Galione, A. TPC: The NAADP discovery channel? Biochem. Soc. Trans. 2015, 43, 384-389. [CrossRef] [PubMed]

66. Peiter, E.; Maathuis, F.J.; Mills, L.N.; Knight, H.; Pelloux, J.; Hetherington, A.M.; Sanders, D. The vacuolar $\mathrm{Ca}^{2+}$-activated channel TPC1 regulates germination and stomatal movement. Nature 2005, 434, 404-408. [CrossRef] [PubMed]

67. Peiter, E. The plant vacuole: Emitter and receiver of calcium signals. Cell Calcium 2011, 50, 120-128. [CrossRef] [PubMed]

68. Hedrich, R.; Mueller, T.D.; Becker, D.; Marten, I. Structure and function of TPC1 vacuole SV channel gains shape. Mol. Plant 2018, 11, 764-775. [CrossRef] [PubMed]

69. Demidchik, V.; Shabala, S.; Isayenkov, S.; Cuin, T.A.; Pottosin, I. Calcium transport across plant membranes: Mechanisms and functions. New Phytol. 2018. [CrossRef] [PubMed]

70. Boccaccio, A.; Scholz-Starke, J.; Hamamoto, S.; Larisch, N.; Festa, M.; Gutla, P.V.; Costa, A.; Dietrich, P.; Uozumi, N.; Carpaneto, A. The phosphoinositide PI $(3,5) \mathrm{P}_{2}$ mediates activation of mammalian but not plant TPC proteins: Functional expression of endolysosomal channels in yeast and plant cells. Cell. Mol. Life Sci. 2014, 71, 4275-4283. [CrossRef] [PubMed]

71. Kintzer, A.F.; Stroud, R.M. Structure, inhibition and regulation of two-pore channel TPC1 from Arabidopsis thaliana. Nature 2016, 531, 258-262. [CrossRef] [PubMed]

72. Patel, S.; Penny, C.J.; Rahman, T. Two-pore channels enter the atomic era: Structure of plant TPC revealed. Trends Biochem. Sci. 2016, 41, 475-477. [CrossRef] [PubMed]

73. Brini, M.; Marsault, R.; Bastianutto, C.; Alvarez, J.; Pozzan, T.; Rizzuto, R. Transfected aequorin in the measurement of cytosolic $\mathrm{Ca}^{2+}$ concentration $\left(\left[\mathrm{Ca}^{2+}\right]_{\mathrm{c}}\right)$. A critical evaluation. J. Biol. Chem. 1995, 270, 9896-9903. [CrossRef] [PubMed]

74. Zonin, E.; Moscatiello, R.; Miuzzo, M.; Cavallarin, N.; Di Paolo, M.L.; Sandonà, D.; Marin, O.; Brini, M.; Negro, A.; Navazio, L. TAT-mediated aequorin transduction: An alternative approach for effective calcium measurements in plant cells. Plant Cell Physiol. 2011, 52, 2225-2235. [CrossRef] [PubMed]

75. Sello, S.; Moscatiello, R.; Mehlmer, N.; Leonardelli, M.; Carraretto, L.; Cortese, E.; Zanella, F.G.; Baldan, B.; Szabò, I.; Vothknecht, U.C.; et al. Chloroplast $\mathrm{Ca}^{2+}$ fluxes into and across thylakoids revealed by thylakoid-targeted aequorin probes. Plant Physiol. 2018, 177, 38-51. [CrossRef] [PubMed]

76. Kistner, C.; Matamoros, M. RNA isolation using phase extraction and LiCl precipitation. In Lotus Japonicus Handbook; Márquez, A.J., Ed.; Springer: Dordrecht, The Netherlands, 2005; pp. 123-124.

77. Colcombet, J.; Hirt, H. Arabidopsis MAPKs: A complex signalling network involved in multiple biological processes. Biochem. J. 2008, 413, 217-226. [CrossRef] [PubMed]

78. Nafisi, M.; Goregaoker, S.; Botanga, C.J.; Glawischnig, E.; Olsen, C.E.; Halkier, B.A.; Glazebrook, J. Arabidopsis cytochrome P450 monooxygenase 71A13 catalyzes the conversion of indole-3-acetaldoxime in camalexin synthesis. Plant Cell 2007, 19, 2039-2052. [CrossRef] [PubMed] 
79. Mao, G.; Meng, X.; Liu, Y.; Zheng, Z.; Chen, Z.; Zhang, S. Phosphorylation of a WRKY transcription factor by two pathogen-responsive MAPKs drives phytoalexin biosynthesis in Arabidopsis. Plant Cell 2011, 23, 1639-1653. [CrossRef] [PubMed]

80. Birkenbihl, R.P.; Diezel, C.; Somssich, I.E. Arabidopsis WRKY33 is a key transcriptional regulator of hormonal and metabolic responses toward Botrytis cinerea infection. Plant Physiol. 2012, 159, 266-285. [CrossRef] [PubMed]

81. Uknes, S.; Dincher, S.; Friedrich, L.; Negrotto, D.; Williams, S.; Thompson-Taylor, H.; Potter, S.; Ward, E.; Ryals, J. Regulation of pathogenesis-related protein-1a gene expression in tobacco. Plant Cell 1993, 5, 159-169. [CrossRef] [PubMed]

82. Maleck, K.; Levine, A.; Eulgem, T.; Morgan, A.; Schmid, J.; Lawton, K.A.; Dangl, J.L.; Dietrich, R.A. The transcriptome of Arabidopsis thaliana during systemic acquired resistance. Nat. Genet. 2000, 26, 403-410. [CrossRef] [PubMed]

(C) 2018 by the authors. Licensee MDPI, Basel, Switzerland. This article is an open access article distributed under the terms and conditions of the Creative Commons Attribution (CC BY) license (http://creativecommons.org/licenses/by/4.0/). 